\title{
En politisk læreproces fra 1980'erne \\ - Folketingets Aktionsplan for kvindeforskning
}

\section{Af Hilda Rømer Christensen}

Folketingets Aktionsplan for Koindeforskning bar haft en central placering i fortallingen om dansk kønsforskning. En succes, som måske bar skygget for det, som er sket siden hen? Hvordan kan konsforskning $i$ dag bidrage med nye perspektiver og argumenter $i$ den forskningspolitiske debat?

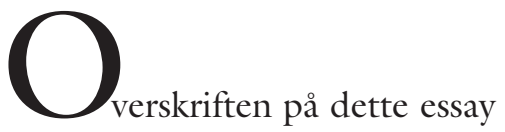
lyder umiddelbart bureaukratisk og gabende kedsommelig, men jeg vover alligevel pelsen og tager afsxt i det, der efter mange debatter og forhandlinger og nogen modstand endte med at blive til Folketingets Aktionsplan for Kvindeforskning. Initiativet, der løb fra 1986 til 1992, blev på mange måder afgørende for, at kvindeforskningen i Danmark overlevede og opnåede en vis institutionalisering efter de turbulente og livlige mobiliseringsår i 1970'erne. Når jeg her næsten 30 år efter finder det interessant at kigge på sagen igen, er det ikke kun fordi Aktionsplanen har været et fast referencepunkt i dansk kønsforsknings historie lige siden. Det er også, fordi planen rakte ud over sig selv i den forstand, at den blev afsæt for det, som man kan kalde diskursiveringen af kvinde-/kønsforskningen i den politiske offentlighed. Aktionsplanen eller hvad man i dag ville kalde et forskningsprogram for kvindeforskning - bestod af en særlig pulje lektorater til kvindeforske- 
re, af løse forskningsmidler til vækstlaget og af bevillinger til dokumentation, information og arkivvirksomhed, som banede vejen for, at KVINFO i København og Kvindehistorisk Samling i Aarhus kom ind i mere faste institutionelle rammer.

Aktionsplanen blev til i en proces, som var både skabt og betinget af et ret unikt samspil mellem kvindeforskere, kvindepolitisk aktive medlemmer af folketing og forskningsråd og nogle af kvindeorganisationerne. Hæver man sig et øjeblik over selve handlingsforløbet, kan man vælge at se forløbet i et policy-perspektiv og som en politisk læreproces, hvor det lykkedes forskellige entreprenører - forskere, politikere og miljøer - at åbne et nyt policy-vindue og at få kvindeforskning sat på den politiske dagsorden. Policy-tilgangen anslår dynamikken mellem forskellige aktører i en given politisk proces og de tråde, som væver sig ind i den formelle og afgrænsede politiske proces. Det var således ikke afgørende, om aktørerne befandt sig uden for eller inden for de formelt valgte organer, men at de var kvalificerede og forberedte, og at de fik etableret en vellykket proces, hvor ligestillingsinteresserede politikere spillede tæt sammen med kvindeforskerne. Hele forløbet kan også med inspiration fra bevægelsesforskningen ses i et såkaldt 'framing'perspektiv, hvor policy ses som interaktive processer. I denne sammenhæng var det målrettede aktører - kvindeforskere og politikere med en bestemt dagsorden - der brugte de forhåndenværende diskursive muligheder eller rammebetingelser til at lancere nye fortolkninger og politiske løsninger. Uanset hvilken tilgang kan man inden for disse kontekster tale om et vellykket forløb, som var både produceret og betinget af et ret enestående samspil på et unikt historisk tidspunkt (Florin 1999; Marx Ferree 2006).

De nye, men kortvarige og skrøbelige alliancer mellem forskere og politikere var også betinget af, at aktørerne stort set tilhørte den samme generation med rod i den nye kvindebevægelse i 1970'erne. En pionergeneration, som satte mange nye og radikale emner på dagsordenen. ${ }^{1}$ I dag er situationen, som alle ved, en anden, og kønsforskere, forskningsråd og politikere står over for nye udfordringer som følge af de køns- og universitetspolitiske opbrud, som har mangfoldiggjort interesser, forskningsparadigmer og politiske projekter. Dette vender jeg tilbage til i slutningen af essayet.

\section{ET RHIZOMISK FORLØB}

Jeg skal i det følgende afdække et beskedent hjørne af denne proces og hovedsageligt fokusere på, hvordan debatten udspillede sig i det danske Folketing. Forslaget om forbedrede vilkår for kvindeforskningen bølgede frem og tilbage $\mathrm{i}$ årene op til vedtagelsen i 1984-85, og forløbet vidner om, at selv dengang i de gyldne 1980'ere var tingene ikke helt så ligetil, som mange af os går rundt og tror. Jeg vil belyse denne debat ganske detaljeret af flere grunde: fordi det mig bekendt ikke er gjort tidligere, fordi kildematerialet er nogenlunde tilgængeligt, og fordi debatten forhåbentlig kan inspirere forskere, forskningsråd og politikere til at iværksætte nye og offensive aktiviteter her i det 21. århundrede.

I begyndelsen af 1980'erne var institutionaliseringen af kvindeforskning ganske beskeden. De fleste af dem, der kaldte sig kvindeforskere, sad på de yderste pladser på universiteter og andre steder, som stipendiater, eksterne lektorer og undervisningsassistenter. Samtidig udgjorde kvinderne, selv efter uddannelsesboomet i 1970'erne, samlet set kun $14 \%$ af det faste akademiske personale ved universiteter og højere læreanstalter, rekrutteringen til nye stillinger stod i stampe, og der var ikke udsigt til, at den nye såkaldte forskerrekrut-plan ville rette op på dette. Kort sagt stod en hel generation af hovedsageligt kvindelige forskere med speciale i kvindeforskning uden faste jobs, og et nyt og lovende forskningsfelt med nye rekrutteringsmuligheder og rolle- 
modeller for kvindelige studerende var i fare for at gå tabt. En situation, som både forskere og politikere fandt uacceptabel.

Modsat mine forventninger var selve forløbet ganske langtrukkent og rhizomisk med mange spillere og tråde, der gik på kryds og tværs. Kønsforskerne havde i begyndelsen af 1980'erne en løs samarbejdsstruktur og ikke nogen forening med protokoller, beslutningsprocedurer og valgt leder eller talsperson. ${ }^{2}$ Det betød, at der var mange involverede i processen, enkeltpersoner som miljøer, og at der givetvis også har været uenigheder og nuanceforskelle i det, der blev sagt og skrevet til politikerne. De centrale aktører blandt kvindeforskerne tilhørte alle, hvad jeg vil kalde førstegenerations-kvindeforskerne i Danmark, hvoraf nogle senere blev ansat i den nye lektorpulje. Vækstlaget eller anden generation af kvindeforskere, som jeg selv tilhørte, havde en mere perifer placering i den beskrevne proces. Mange herfra fik dog mulighed for at søge de løse forskningsmidler i Aktionsplanen, der for en dels vedkommende førte til faste universitetsansættelser. ${ }^{3}$

Fra det foreliggende ufuldstændige kildemateriale kan forløbet løseligt konstrueres som følger: De første konsultationer mellem forskere og politikere fandt sted i løbet af 1983, hvor kønsforskerne kontaktede og fik foretræde for Folketingets Forskningsudvalg. Anledningen var bl.a., at den femårige bevilling til kønsforskning i Statens Humanistiske Forskningsråd ville udløbe i 1984, og både forskere og politikere ønskede nogle mere samlede og offensive initiativer. ${ }^{4}$ I Folketinget sad der efter valget i 1984 en markant gruppe af ligestillingsinteresserede kvindelige politikere, nogle af dem med centrale placeringer i Folketingets Forskningsudvalg. ${ }^{5}$ Det første udkast til Folketingets beslutningsforslag forelå allerede i december 1983, men blev af forskellige grunde forst fremsat og nedstemt i maj 1984, for derefter at blive genfremsat i oktober 1984. Hele initiativet blev efter dette og efter anbefaling fra Folketingets Forsk- ningsudvalg, udmøntet i Aktionsplanen for forbedrede vilkår for kvindeforskning i løbet af 1985 (Styringsgruppen for kvindeforskning 1992, Bilag 2: 165). Forskere og politikere fulgte sagen on and off og spillede direkte ind til processen og sørgede for offentlig bevågenhed i kronikker og debatindlæg, ved møder og på pressekonferencer. ${ }^{6}$ Argumenterne for Aktionsplanen blev også underbygget af gode eksempler fra de $\varnothing$ vrige nordiske lande. Mens Sverige satsede på en decentral udvikling og havde allokeret ressourcer til opbygning af kvindeforskningscentre ved de enkelte universiteter, blev der i Norge oprettet et centralt sekretariat for kvindeforskning, som i de følgende år fik stor betydning. Aktionsplanen i Danmark indebar en kombineret model, med udbygning og etablering af kvindeforskning på de enkelte universiteter, med lektorater og stipendiater og med etablering af en central koordinerende enhed. 7 At dette var hårdt tiltrængt $\mathrm{i}$ en tid uden internet, mail, sms og blogs vidner følgende lille situationsrapport om:

Ud af de sidste 3-4 dage, hvor min telefonregning er steget astronomisk og hvor jeg alligevel sidder tilbage med en følelse af, at der er mange, der ikke er blevet informeret, selv om de burde - ud af dette føler jeg et behov for mere faste kontaktformer og kontakt-forpligtelser indadtil i ens eget miljø (der jo både er geografisk og fagligt og på tværs af geografi) og mellem miljøerne. [...] Jeg vil sige: et sekretariat for kvindeforskning med en, helst flere, ansatte kvindeforskningskoordinatorer. Men bare et eller andet. Jeg er død træt!

Brevet slutter dog nok så optimistisk:

Med kvindeforskningshilsen (det går jo trods alt fremad) Drude. ${ }^{8}$

Og fremad gik det. I Folketinget blev forslaget om forbedrede vilkår for kvindeforskning initieret af en gruppe overvejende kvindelige politikere fra SF, S og VS. Det 
indeholdt en række konkrete indsatsområder for kvindeforskningen og forslag om, at der skulle tilføres øremærkede midler. Det er sigende, at Radikale Venstre, som var parlamentarisk nødvendig til etablering af et 'alternativt' flertal til den siddende borgerlige regering, var tøvende og i forløbet fremsatte et konkurrerende forslag som var mere abstrakt og uden konkret allokering af ressourcer. ${ }^{9}$

Forslaget fra Socialdemokratiet, SF og VS omfattede i den oprindelige udgave følgende punkter:

1. Særlige bevillinger til kvindeforskningen og kvindelige forskere, eventuelt med udgangspunkt i de tværvidenskabelige kvindeforskningsmiljøer samt til opbygning af sådanne.

2. En særlig bevilling til det daværende ligestillingsråd til finansiering af forskningsog udredningsarbejde inden for kvinde- og ligestillingssektoren.

3. En særlig bevilling til oprettelse af videnskabelige heltidsstillinger ved universiteter o.l. til kvindeforskning og undervisning $\mathrm{i}$ kvindeforskning.

4. Offentlig støtte til udbygning af kvindeforskningens informations-, dokumentations-, registrerings- og arkivopbygningsvirksomhed. Økonomisk støtte til formidling af kvindeforskning til et bredere publikum end forskerne selv.

5. De højere læreanstalter skulle påse, at der "sker en så ligelig fordeling som muligt af kvinder og mænd til forskerstillingerne, $o g$ at kvindelige synsvinkler på forskningen generelt tilgodeses".

6 . Ved udpegning af medlemmer til universiteters styrende organer og til forskningsrådene skulle der sigtes mod ligelig fordeling af kvinder og mænd. 10

7. Der skulle fastsættes en økonomisk ramme med mindst 5.5 mio. kr. i 1986 og 7 mio. kr. i 1987 og fremefter.

8. Der skulle nedsættes et fordelingsudvalg. Det skulle bestå af en repræsentant fra hvert af de 5 universiteter og centre samt 2 udpeget i fællesskab af Danmarks Tekniske Højskole, Handelshøjskolerne og Danmarks Lærerhøjskole, samt en studenterrepræsentant. ${ }^{11}$

Alt i alt blev debatten ført i spændingsfeltet mellem den liberale forståelse af kvinder som det andet køn og tesen om, at kvinderne ikke var på højde med mændene i kapløbet om stillinger på den ene side og en mere kritisk forståelse af den eksisterende forskningsverden på den anden side. De radikale argumenterede for, at "kvalifikationskravene er således, at de færreste kvinder vil have haft mulighed for at erhverve sig disse kvalifikationer, hvis de skal opretholde et sædvanligt kvindeliv. De unge kvinder har hovedansvaret for familie og børn og har i de unge år ikke mulighed for at opbygge de fornødne forskningsmæssige kvalifikationer inden for de år af livet, hvor mænd traditionelt gør det" (Bemærkning til B 11, sp. 2). I venstrefløjens optik blev den ensidige sammensætning af forskersamfundet set i et bredere samfundsmæssigt perspektiv og som en svaghed for forskningen:

Hvis livshorisonter vil sådanne forskere have, som fratages retten til at få børn og være socialt ansvarlige i en lang periode af deres arbejdsliv, som lader andre udføre det nødvendige familiearbejde (Steen Tinning, VS: Forhandling 8.5.84 sp. 5747).

KVINDE, FORSKNING OG LIGESTILLING. ETABLERING AF EN POLITISK GRAMMATIK

Motiveringen af initiativet havde det, som man i dag vil kalde stærke standpunktsteoretiske indslag, og betonede, at kvinders synsvinkel havde særlige fortrin, hvilket formentlig var helt $\mathrm{i}$ tråd med mange kvindeforskeres holdninger på dette tidspunkt. ${ }^{12}$ Det var mere eller mindre selvklart, at kvindeforskere bestod af kvinder, og at kvinder ville bringe nye synsvinkler ind i forskningen. 
Kvinder stiller andre spørgsmål end mænd. Når man forsker, drejer det sig om at stille spørgsmål. Baggrunden for fremsættelsen af dette forslag er, at vi mener, at det er utrolig nødvendigt, at kvinder ud fra deres forudsætninger og med de erfaringer, som de har ud fra deres køn, stiller de spørgsmål, som skal stilles. Naturligvis er det også vigtigt, at mænd stiller spørgsmål, men vi kan ikke i et samfund nøjes med, at der kun stilles spørgsmål ud fra et køns forestillinger om verden (Alice Faber: Forhandling 7.5.84, sp. 5749).

Ligesom vigtigheden af kvindelige eksperter blev betonet:

Et så vigtigt område som seksualforskning har i mange, mange år været et mandsområde.

Mænd har vidst, hvordan kvinder følte, hvordan det var for kvinder i puberteten, hvordan det var for dem i klimakteriet. [...] Kvinderne skal med med deres viden med deres erfaringer. Kvinderne må være med og som baggrund for deres handlen have en forskning om kvinder, som sxtter dem i stand til at handle både intellektuelt og følelsesmæssigt i overensstemmelse med de kvinder, som de repræsenterer, og som de forsvarer (Ingerlise Koefoed: Forhandling 7.5.84, sp. 5744$45) .13$

Derudover blev der også peget på mangfoldigheden i kvindeforskningen:

Det er ikke muligt at formulere en entydig definition af kvindeforskningen: dertil er den for mangesidig, og de enkelte kvindeforskere har alt for forskellige grundholdninger. Kvinders situation kan anskues ud fra forskellige indfaldsvinker uden at disse dog gensidigt behøver at udelukke hinanden (Bemærkning til forslag. 22.3.1984, sp. 2).

Også kvindeforskningens bredde og rækkevidde ud over det akademiske blev fremhævet og var indlejret i forslaget om, at det daværende Ligestillingsråd skulle råde over en pulje til fordeling til relevante temaer som arbejdsmarked, sundhed, den sociale struktur osv. Og endelig blev opgaver som dokumentation og formidling set som vigtige og nævnt adskillige gange i debatten.

Under forhandlingerne var det karakteristisk, at flere partier forskød problemstillingen til ligestillingsmæssige og generelle forskningspolitiske argumenter. Positioneringerne er interessante, fordi de etablerede en slags grammatik og et felt for forhandling af køn og forskning, som også kan aflæses i dag.

Undervisningsminister Bertel Haarder og partiet Venstre var allerede her på banen med de i dag velkendte liberale mantraer om fri konkurrence og meritokrati. Han syntes ikke, der var grund til særlige initiativer og mente, at kvindeforskningen skulle måles på, om den kunne klare konkurrencen med den generelle forskning:

Forslagsstillerne skriver selv, at der er en positiv udvikling i gang på kvindeforskningsområdet, og at den ekspansion i kvindeforskningen, som har fundet sted inden for de sidste 10-12 år, har været ensbetydende med en vigtig kvalitativ forbedring af forskningsniveauet. Det er jeg enig med forslagsstillerne i, og derfor synes jeg, man skulle lade denne udvikling fortsætte i fred og ro under de slet ikke så dårlige betingelser, som bliver forskningen til del i de kommende år. [...] jeg synes vi skal blive ved med at lade de mest kompetente forskere, vi har, se kvindeforskningen i sammenhæng med al mulig anden forskning og satse på kvaliteten fremfor at skulle administrere bestemte øremærkede bevillinger til bestemte formål (Forhandling 7.5.84, sp. 5739).

Kristeligt Folkeparti og de konservative støttede undervisningsministeren, de konservative med den tilføjelse, at der skulle satses mere på erhvervsforskning, og at de dertil var imod kvotering:

Vi har ønsket om, at vi øger andelen af kvindelige forskere og af kvinder overalt i samfun- 
det, men vi har ikke noget ønske om et formelt krav om, at der skal ansættes lige mange kvinder og mænd overalt i samfundet, eller at de på anden vis skal kvoteres. Vi ønsker ikke folk ansat udelukkende på et kønskvoteringskrav (Forhandling 7.5.84, sp. 5742).

Omvendt talte Steen Tinning fra VS for positiv særbehandling på grund af den ulige konkurrence i forskningsverdenen. Selvom han undrede sig over, at man i Holland havde noget "så besynderligt som emancipationsfunktionærer", så pegede han som den eneste også på forhold inden for institutionerne og den ulige konkurrence i den akademiske verden som argument for den særlige satsning.

(...) konkurrencen mellem den dominerende, velkendte mandsforskning - hvad vi nu vil kalde det - og den særlige kvindeforskning, er en konkurrence, der selvfølgelig foregår på ulige vilkår, på dårligere betingelser for kvinderne. Af præcis samme grund er det nødvendigt med en positiv særbehandling af kvindeforskning (Forhandling 7.4. 84, sp. 5749).

Fremskridtspartiet ved Pia Kjærsgaard var lodret imod det, der blev set som dyre og overflødige aktiviteter:

(...) vi ønsker ikke, at der skal bruges 18 mill. de næste 3 år, fordi der skal forskes af kvinder, oprettes registre, arkiver og andre overflødige ting. [...] Vi skal ikke ved lov få ligestilling. Det må stadig væk være afgørende om kvalifikationskravene er opfyldt. Fremskridtspartiet siger blankt nej til dette selvforherligende forslag (Forhandling 7.5.84, sp. 5746).

De radikale gik som sagt solo og sprang $\mathrm{i}$ 11. time fra støtte til forslaget $\mathrm{i}$ foråret 1984. Partiet fremsatte senere deres eget indspil i efteråret 1984, til stor fortrydelse for de kvindelige politikere og kønsforskerne. "Det er fantastisk, at de radikale nu sinker sagen. Forslaget går helt tilbage til 1983, og allerede dengang indbød vi de ra- dikale til at være med. Lige siden har vi arbejdet med sagen og får først nu besked på, at partiet alligevel trækker sig helt ud. De radikales opførsel i denne sag er fuldstændig urimelig og et udslag af renlivet partiegoisme" klagede Mette Groes i en stort opsat artikel i dagbladet Aktuelt (Groes 1984).

Det Radikale Venstre var enige i, at der var tale om et nyt væsentligt forskningsområde, som burde fremmes, både ved at forbedre vilkårene for kvindeforskningen og ved at øge antallet af kvindelige forskere. Kvindeforskning var vigtig, men "kvindeforskning bør som sådan ikke isoleres fra anden forskning, men bør være en integreret del af de allerede eksisterende forskningsmiljøer". Fx burde den historiske kvindeforskning være en del af et historisk forskningsmiljø, medicinsk kvindeforskning del af et medicinsk forskningsmiljø etc. Som sådan forfægtede de radikale det, man i dag ville kalde en kønsmainstreaming-strategi, og mente, at midler til kvindeforskningen "kan findes indenfor de allerede eksisterende rammer og kan fordeles via de eksisterende forskningsråd" (Bemærkninger til B 11, sp. 2 og 3).

Det er interessant, at de radikale pegede på et bredere ligestillingsperspektiv i front mod den ensidige kvindesynsvinkel og argumenterede med, at "vi gerne ser kvindeforskningen fremmet ud fra et demokratisk ligestillingsperspektiv. I modsætning til forslagsstillerne mener det radikale venstre f.eks. at kvindeforskningen også ganske udmærket kan udføres af mænd" (Inger Marie Bruun-Vierø: Forhandling 7.5.84, sp. $5745)$.

Det er værd at bemærke, at alle minus det daværende Fremskridtsparti spillede sig ind med mere og især mindre forpligtende velvilje. Og at initiativet faktisk blev en realitet trods disse forbehold og forsøg på benspænd og modstand fra ressortministeren. Det er også interessant, at de radikale var på banen med det, som man i dag kan kalde kønsmainstreaming light, og i den 
gratis udgave, hvor der ikke var konkrete bud på de fine hensigter. Og man kan vel roligt og lidt syrligt sige, at det siden dengang er den radikale - velvillige, men også uforpligtende - tankegang, som har vundet terræn i dansk forsknings- og universitetspolitik.

\section{REFLEKSIONER}

Der er nu gået 20 år siden Aktionsplanen blev afsluttet med besked om, at kvindeforskningen måtte klare sig selv og skulle integreres i de almindelige forskningsråd og satsninger. Aktionsplanen blev fulgt af et slags backlash, og 1990'erne blev af mange aktive kvinde-og kønsforskere oplevet som et tiår, hvor alting gik op ad bakke. Særlig betydning fik det, at den centrale platform med programmidler, styregruppe, sekretærer og koordinatorer placeret $\mathrm{i}$ tæt tilknytning til forskningsrådssystemet forsvandt. Det skete sigende nok næsten samtidig med udskiftning af en del af de politikere, som havde gjort en aktiv indsats for Aktionsplanens realisering.

Men måske kom Aktionsplanen og flowet i 1980'erne også til at skygge for, at der i 1990'erne blev søsat en række nye og blivende søjler i dansk forskning? Foreningen for Kønsforskning med tilhørende årlige konferencer. Det videnskabelige tidsskrift Kvinder, Kon \& Forskning og Koordinationen for Kønsforskning, der uanset op- og nedture har overlevet alle turbulenser. Man kan vel godt og ret ubeskedent sige, at det er disse aktiviteter, der har garanteret en vis kontinuitet og en ganske effektiv infrastruktur i dansk kønsforskning i de to seneste årtier. Ligesom der i 1990'erne faktisk også var en del ting, som rykkede i forskningspolitikken og bevillingerne. Jytte Hilden, aktivistisk forskningsminister fra 1996 til 1998 med interesse for køn og ligestilling, iværksatte en hel vifte af initiativer, hvoraf forskningspolitiske rundbordssamtaler, 11 punkts plan og FREIA-projektet med hele 78 millioner kroner til kvindelige forskere var de vigtigste. Dertil kom betydelige forskningsrådsbevillinger til det såkaldte Kønsbarriereprojekt og til GEP Gender, Empowerment, Politics, ligesom EU's forskningspolitik begyndte at fokusere på køn og ligestilling. Aktiviteter, som økonomisk set kom til at overstige de bevillinger, der var givet til Aktionsplanen, men som ikke i erindringspolitisk forstand har haft nær så stor betydning i fortællingen om dansk kønsforskning.

Kønsforskning har efter min mening den styrke, at forskningen til stadighed er båret af både et teoretisk/analytisk og et politisk ønske om forandring. Et forhold, som hele tiden sikrer, at dynamikken, adrenalinen, intellektet og nysgerrigheden bliver holdt intakt. Konferencen Feminist Materialisms, som for nyligt blev afholdt på Københavns Universitet, er et frisk eksempel på, at kønsforskningen også i dag er i stand til at sætte dagsordenen for nye samfundskritiske og tværvidenskabelige turns, der sammentænker krop, materialitet og kultur og samfund på nye måder. Hvordan kan dette flow følges op af et nyt spring fremad? Er det i dag med inspiration fra kønsforskningens indsigter og nye transnationale policy-processer muligt at rykke ved de forståelser og argumenter, som blev brugt i 1980'erne? Hvad betyder fx det manifeste opbrud fra den emancipationspolitiske dagsorden og mangfoldiggørelse af ligestillingsperspektiverne $\mathrm{i}$ det 21 . århundrede? Hvordan kan kønsforskningen bidrage til at formulere nye kosmopolitiske og transformative ligestillingspolitikker? Og hvordan kan dette udmøntes i nye temaer og tilgange fx i kønsmainstreaming af forskningsprogrammer som det danske Forsk 2020 og det europxiske Horizon 2020?

Lige nu ser de institutionelle betingelser ud til at være optimale for at åbne et nyt policy-vindue med henblik på at styrke disse nye perspektiver og køn i forskning. Ikke alene tegner kønsforskere sig i dag for et historisk højt antal lektorater og professorater inden for den almindelige stillingsstruk- 
tur; forskningsrådene har også aktuelt adskillige kønsforskere som medlemmer med indflydelse på prioriteringer og bevillinger. Danmark har endelig i skrivende stund en række indflydelsesrige forskningspolitiske ordførere, der med inspiration fra EU's forskningspolitiske strategier er stemt for nye initiativer, når det gælder køn i forskning. Men ligesom i 1980'erne sker dette ikke af sig selv, og der ligger en stor opgave $i$ at få dialogen og interaktionen mellem forskere, politikere og forskningsrådsmedlemmer gjort mere kontinuerlig, målrettet og visionær.

I forbindelse med udarbejdelsen af dette essay konsulterede jeg arkivalierne i det, der stadig kalder sig Kvindehistorisk Samling på Statsbiblioteket i Aarhus. Arkivet fungerer nu, efter årtiers udsultning, som en fritsvævende materialesamling uden de nødvendige arkiv- og fagressourcer. Det fortæller måske bedre end så meget andet om, at Aktionsplanen og efterfølgende initiativer kun tilvejebragte en slags time out og pusterum for kønsforskningen. Ligesom det minder om, at ressourcer og positioner, institutioner og tidsskrifter ikke bare er noget, som er der, men at det er noget, der skal holdes ved lige, fornyes og ikke mindst kæmpes for. Og måske kan vi også her lære noget af energien, frygtløsheden og fællesskabet i 1980 'ernes politiske processer?

\section{NoTer}

1. Radikaliteten gjaldt både forskning og politik, se fx Mette Kunøes festlige beskrivelse af SF's kvindearbejde i Kunøe (1984). Mette Kunøe, lektor og afdelingsleder ved Nordisk Institut på Aarhus Universitet, fik en central placering i institutionaliseringen af dansk kønsforskning, som medlem af Statens Humanistiske Forskningsråd 1978-1986, som leder af Styregruppen for Kønsforskning 1986$1992 \mathrm{og}$ som forkvinde for KVINFO's bestyrelse 1992-1995.

2. Godt nok var der i 1982 etableret et forum for kvindeforskere i Danmark, "absolut uden jubel eller med den store begejstring", som Bente Ro- senbeck skriver i anledning af 5-års-jubilæet i 1987 (Rosenbeck 1988: 5-8). Dette forum levede stille, indtil det blev kaldt til live igen i 1984 i forbindelse med folketingsbeslutningen, jf. brev fra AnnaBirte Ravn til kontaktpersoner, 7. maj 1984.

3 . Følgende blev ansat i de 8 kvindeforskningslektorater: Bente Rosenbeck, KU; Birgit Petersson, KU; Elisabeth Flensted-Jensen, AU; Drude Dahlerup, AU; Nina Lykke, OU; Kirsten Simonsen, RUC; Anna-Birte Ravn, AUC og Karen Borgnakke, DLH/DPU. Om generationsmæssige brudflader i 70'ernes fagkritiske kultur se Rømer Christensen, Floris og Jensen (1978).

4. Jf. Rosenbeck (1988: 7). Udover det særlige initiativ i Statens Humanistiske Forskningsråd med en årlig bevilling på $400.000 \mathrm{kr}$. i fem år, var der givet beskedne bidrag fra det Lxgevidenskabelige Forskningsråd til den første konference for medicinsk kvindeforskning ligesom det centrale Planlæagningsråd for Forskning havde allokeret to stipendier til kvindeforskning.

5. Med Alice Faber fra SF og Sonja Mikkelsen fra S som henholdsvis formand og næstformand for Folketingets Forskningsudvalg + en række aktive politikere, som var med til at fremsætte forslaget.

6. Forskningsudvalget nævner i Beretning af 22 . maj 1985, at der i processen var kommet mundtlige og skriftlige henvendelser fra: Center for Kvindeforskning og -undervisning, Københavns Universitet; Center for Kvindestudier, Odense Universitet; Center for tværfaglig information om kvindeforskning; KVINFO; Forum for Kvindeforskning ved Danmarks Lærerhøjskole; Handelshøjskolen i Århus; Håndbibliotek for kvindeforskning, Århus Universitet; Kvindeforum, Ålborg Universitetscenter og Kvinder på Tværs, Roskilde Universitetscenter. Der blev også i arkivalierne henvist til en kronik af Birte Siim i Information d. 13. november 1983, og Kofoed (1984).

7. I starten blev der endda opereret med en koordinator på hvert universitet, men dette blev senere og som led i udmøntningen af planerne reduceret til to halvtidskoordinatorer, en i Jylland og en i København i perioden fra 1986 til 1992. I 1992 blev koordinationen reduceret til én koordinator med forskningsforpligtelse + løse projekt- og forskningsmidler. Koordinatorerne fra 1986-1992 var Anette Borchorst, AU (1986-1987), Ann-Dorte Christensen, AUC (1987-1992) og Anne Margrete Berg, KU (1986-1992).

8. Brev af 6.12.1983 fra Drude Dahlerup til kontaktpersoner på danske universiteter: Dorrit (Schmidt), RUC; Anna Birthe (Ravn), AUC; Nina (Lykke), OU; Mette (Bryld), OU; Lene (Koch), KUA og Nynne (Koch), KVINFO. Det er karakte- 
ristisk, at der kun blev brugt fornavn, efternavn er indsat af HRC.

9. Forslaget blev første gang fremsat i folketingsåret 1983-84 (2. samling). Se Folketingstidende 1983-84 den 22. marts 1984 (2.samling, forhandlingerne sp. 2900, 5839 og 7412, tillæg A sp. 3307 og tillæg B sp. 1199) af følgende politikere: Alice Faber (SF), Hanne Thanning Jacosen (SF), Hanne Andersen (S), Dorte Bennedsen (S), Mette Groes (S), Jytte Hilden (S) og Steen Tinning (VS) og genfremsat 16. oktober som B 16. 1984. Forinden havde Radikale Venstre den 9. oktober fremsat Beslutningsforslag nr. B 11. I det følgende refereres der blot til Forhandling + dato+ spalte. Folketingets udvalg vedrørende videnskabelig forskning afgav den 22. maj 1985 beretning over de to forslag B 11 og B 16, hvori regeringen blev opfordret til at fremlægge en aktionsplan for forbedrede vilkår for kvindeforskningen med virkning fra 1 . januar 1986. I løbet af 1985 blev denne plan udmøntet i et samarbejde mellem Undervisningsministeriet, Planlægningsrådet for Forskningen og Ministeriet for Kulturelle Anliggender. Aktionsplanen forelå i sin endelige form den 19. december 1985 og blev iværksat i begyndelsen af februar 1986.

10. Dette knyttede an til den aktuelle forberedelse af lov om ligestilling mellem kvinder og mænd ved udpegning af medlemmer til offentlige udvalg, kommisioner og lignende, vedtaget i 1985.

11. Den endelige udmøntning af Aktionsplanen afveg på en række punkter fra det skitserede. Puljen til Ligestillingsrådet udgik fx og Styringsgruppen blev nedsat centralt i tilknytning til Forskningspolitisk Råd. Aktionsplanen løb i 3 år fra 1986 til 1989 og blev forlænget med endnu 3 år fra 1989 til 1992, hvilket skete uden de store problemer (jf. samtale med Mette Kunøe, april 2012). Det samlede budget for de to perioder beløb sig til i alt 18 mio. kr., hvortil kom finansiering af 8 kvindeforskningslektorater. Styringsgruppen gav i alt 114 bevillinger, heraf 61 til projekter og rejser (Styringsgruppen for kvindeforskning 1992: 1-2). 12. Fx hed det i logoet for Forum for kvindeforskere i Danmark i 1982: "Forum af kvinder, til fremme af forskning af, om og for kvinder". 13. Også Radikale Venstre opererede med en håndfast definition: "Kvindeforskning har som sin genstand kvinder og kvinders forhold og anskuer disse ud fra kvinders synsvinkel" (RV: bemærkninger til B 11:2).

\section{LITTERATUR}

- Rømer Christensen, Hilda; Floris, Kirsten; Jensen, Lis (1978): Student i Dag, i: Hug, nr. 4. - Florin, Christina (1999): Something in the nature of a bloodless revolution. How new gender relations became gender equality policy in Sweden in the nineteensixtiees and seventies, i: Rolf Torstendahl (red.): State Policy and Gender System in two German States and Sweden 1945-1989, Opuscula Historica, Upsaliensia 22, Uppsala Universitet.

- Groes, Mette (1984): R løber fra aftale om kvinde-forskning, i: Aktuelt, d. 12. maj, 1984.

- Koefoed, Ingerlise (1984): Kommentar: Kvinderne skal have halvdelen, i: Politiken, d. 17. Maj 1984.

- Kunøe, Mette (1984): Tressernes strømninger nåede SF i halvfjerdserne, i: Socialisme på dansk: $S F$ gennem 25 àr, SP Forlag.

- Marx Ferree, M. (2006): Framing Equality: The Politics of Race, Class and Gender in the US, Germany and the Expanding European Union, i: Roth, S. (red): Gender Issues and Women's Movements in the Enlarged European Union. Berghan Books, London/New York.

- Rosenbeck, Bente (1988): Kvindeforskning forskningspolitik - om forum for kvindeforskere i Danmark, i: Kvindeforskning. Nyhedsbrev nr. 1. 1988.

- Styringsgruppen for kvindeforskning (1992): Folketingets Aktionsplan for Kvindeforskning 19861992: Evaluering. Styringsgruppen for Kvindeforskning.

Hilda Rømer Christensen, lektor Koordinationen for Kønsforskning Sociologisk Institut

Københavns Universitet 